\title{
18. Here and Now: Rethinking philosophy of education
}

Torill Strand, University of Oslo (torill.strand@iped.uio.no)

\begin{abstract}
:
The TV-series "Here and Now" (HBO 2018) may be seen as an allegory of the current situation within philosophy of education. The main character is the depressed philosopher Greg Boatwright, father of four: three adopted children - from Liberia, Vietnam and Colombia - and a biological daughter, who calls herself "the boring white chick in the family". Raising this family was to Greg and his wife a "great progressive experiment in diversity". However, on his 60th birthday he delivers a disturbingly pessimistic speech: "It all failed". Later he confides to his daughter: "sometimes I feel like the world's falling apart". Admittedly, today's philosophy of education may fall short of such a bleak description. Nevertheless, in face of such a situation it seems pertinent to re-think philosophy of education, old and new. The aim of this chapter is to explore to what degree Alain Badiou's anti-philosophy may represent a way of doing so.
\end{abstract}

In the first part of this chapter I map out the many faces of current philosophies of education. Next, I perform a close reading of Alain Badiou's "ethics of truths" and "logic of worlds". In doing so, I hope to reveal the ontological assumptions that generate Badiou's philosophical position. In the third part of the chapter I compare and contrast Badiou's position with some contemporary philosophies of education. Referring to Greg's pessimistic speech we may ask: Did they all fail?

Keywords: Alain Badiou; philosophy; education; conditions; events; truths; ethics

\section{Introduction}

The title of this chapter may be associated with the TV-series "Here and Now" (HBO 2018), which can be seen as an allegory of the current situation within philosophy of education in face of social and historical change. The main character is the depressed philosopher Greg Boatwright, father of four: three adopted children - from Liberia, Vietnam and Colombia and a biological daughter, who calls herself "the boring white chick in the family". Raising this family was to Greg and his wife a "great progressive experiment in diversity". However, on his 60th birthday he delivers a disturbingly pessimistic speech: "It all failed". Later he confides to his daughter: "sometimes I feel like the world's falling apart". Philosophy of education may fall short of such a bleak description. Nevertheless we may still consider it pertinent to re-think the potential topicality and relevance of a philosophy of education of and 
for the present. The aim of this chapter is to explore a way of doing so through a diligent reading of some of the key texts of the French philosopher Alain Badiou, as I ask: Could Badiou represent a fruitful way of re-thinking philosophy of education? To what degree may Badiou's philosophy help to strengthen the potential topicality and relevance of a philosophy of education of and for today?

In the first part of this chapter I map out the many faces of current philosophies of education. Next, I perform a close reading of Alain Badiou's "ethics of truths" and "logic of worlds" in order to clarify his mission of rethinking, renewing and thereby strengthening philosophy as an academic discipline. In doing so, I point to the ontological assumptions beyond his position and also the ways in which the pedagogical theme is vital, constitutive, and ongoing throughout his work. Next, I compare and contrast Badiou's position with some contemporary philosophies of education. Referring to Greg's pessimistic speech we may ask: Did they all fail?

\section{The many faces of philosophy of education}

The chapters included in this volume clearly illustrates how contemporary philosophy of education come forward as diverse, many-faceted and numerous engagements with different issues and problems concerning both the fields of philosophy and of education (Phillips, 2010; Strand, 2012). The multiple faces of philosophy of education make it difficult to distinguish this field from other fields of study. However, a common denominator is a strong commitment to various aspects of education. This commitment shapes the course, topics, approaches, methods and dissemination of the work of contemporary philosophers of education.

Philosophers of education frequently use tangible educational situations as points of departure in their philosophical investigations. They tend to draw on their background as educational researchers or former teaching experience in their work. Their ways of performing philosophical analysis therefore often reveal radical approaches and openness to new ideas. This strong commitment to education is also seen in the fact that their work is published in a wide range of journals on educational theory, research and practice, not in philosophy journals. But even though contemporary philosophers of education dedicate their work to the practical discipline of education, there seems to be a tendency to question the social significance of their philosophical work (Clark, 2006; Smeyers, 2006; Strand, 2012).

Consequently, philosophy of education seems to be caught between the academic disciplines of philosophy and of education: On the one hand, it is a daughter of philosophy, drawing from the traditional fields, approaches and methods of its parent discipline. On the other hand, the issues studied concern processes, purposes and ideals of educational theories, policies and practice (Curren, 2007; Phillips, 2010; Siegel, 2009). For example, what constitutes upbringing and education (i.e. Kirsten Hyldgaard's chapter in this volume); what values and norms are revealed through educational policies and practices (i.e. Ole Andreas Kvamme's exploration of moral education and Kalisha Will's analysis of immigrant policies 
and practices in Norway); what are the conditions, possibilities, legitimacies, and limits of education as an academic discipline (i.e. Kjetil Horn Hogstad's chapter on Malabou's notion of plasticity and Carol Taylor's chapter on post-humanism); and how should we understand the relation between educational theory and practice (i.e. Henrik Vase Frandsen's chapter on Didrich Benner's theory or Claudia Schumann's excellent analysis of 'thinking in education"). The ambition is not necessarily to contribute to philosophy, but rather to contribute to educational theory and practice. Thus, it may seem relevant to determine philosophy of education as a field of philosophical inquiries that "focuses upon issues arising within the domain of education" (Phillips, 2010, p. 18). However, the danger is that such a definition may conceal the distance between philosophy and education.

In contrast to a tentative covering of the distance, Badiou points to the fruitful gap between philosophy and real life. To him, it is exactly this distance that conditions and justifies philosophy (Badiou, 1992; 2001; 2006; 2011a). On the one hand, Badiou holds that "philosophy is not worth an hour's effort if it is not based on the idea that the true life is present" (Badiou, 2009b, p. 14). On the other hand, he argues that philosophy should never be mixed up or confused with real life. Philosophy is different from real life. And real life can never be turned into philosophy. Badiou therefore maintains that a genuine philosopher commits herself to the incommensurable relation between the rules of philosophy and the ordinary rules of life. Because this relation - which is not a relation - conditions philosophy:

I insist on this point: it is not because there is 'something' that there is philosophy. Philosophy is not at all a reflection on anything whatsoever. There is philosophy, and there can be philosophy, because there are paradoxical relations, because there are breaks, decisions, distances, events (Badiou, 2009b, p. 16).

In other words, Badiou holds that real life always precedes and conditions philosophy. Moreover, that philosophy must never be confused with or mixed up with real life. But how may this concern a philosophy of education of and for the present? Before exploring that question, we should take a brief look at Badiou's philosophical system and its inherent pedagogical operations.

\section{True life should be present}

It should be said that Badiou belongs to the group of contemporary French philosophers ('nouveaux philosophes') who, in the wake of poststructuralism, postmodernism and deconstruction, seek to renew philosophical thinking by developing a new type of materialistic realism. This new school diverges from the preceding generation by rejecting the linguistic, textual or discursive paradigm of their predecessors (such as Deleuze, Derrida and Foucault), rethinking the question of materiality, and exploring the nature of change (James, 2012; Hallward, 2003).

Alain Badiou develops his philosophical system through three books: Being and Event (2005b), Logics of Worlds: Being and Event II (2009a), and Immanence of Truths: Being and 
Event III (forthcoming). This Being and Event trilogy is key to his ontology, which is based on mathematical set theory. However, the three books also reveal how his philosophy has developed, and his ontological thinking has deepened over time. In the first book, Badiou develops his main concepts of being, truths and event. Here he exposes an ontological (some would say a phenomenological) position, which elegantly deconstructs the idealism and romanticism in Heidegger. Being, to Badiou, is multiple and void. There is no ultimate consistency or unity to being. Truths, which are generic, always belong to particular situations. However, truths - which are subjects to unpredictable events - cut through established knowledge. Truths thus imply some kind of 'logical revolt' against the situation. In the next book, he attempts to describe in more detail the appearing and disappearing of truths-in-worlds. "I insist, since this is the very problem that this book is concerned with: truths not only are, they appear," (Badiou, 2009a, p. 9). Such truth-procedures are immanent exceptions. In the third book (published in French in 2018), he returns to the notion of immanence. However, here he reverses the perspective by examining truths, not from the point of view of the worlds from which they emerge, but from the point of view of truths themselves. Truths are existential, ongoing and open-ended ontological operations that do not belong to any epistemic category. It is upon this background we should read his axiom that "the only education is an education by truths," (Badiou, 2005a, p. 14).

Badiou has not written extensively on education, but the pedagogical theme is vital, constitutive and ongoing throughout his work (Strand, 2020). In the essay Art and Philosophy, Badiou portrays education as a transformative, open-ended and ongoing procedure instituted by an exception, a rupture, or event. Furthermore, Badiou's hypertranslation of Plato's Republic (2012a) can be taken to illustrate how these open-ended pedagogical operations of truths-in-worlds may cultivate the young (Bartlett, 2011; Strand, 2016). His conception of these pedagogical operations are also key to the essay The True Life (2017), which is based on lectures delivered to groups of youths in high schools and seminars, both in France and elsewhere. Badiou's message to the young is that "to attain the true life we have to struggle against prejudices, preconceived ideas, blind obedience, arbitrary customs, and unrestricted competition" (Badiou, 2017, p. 8). In short, an education by truths operates through a subtraction from the state of the situation and proposes a different direction as regards to the true life (Bartlett, 2006; Heyer, 2010). In sum, the inherent pedagogical operation within Badiou's anti-philosophy teaches the power of the unthinkable.

Consequently, Badiou's anti-philosophy may well inform the discussion on the aims and mission of a philosophy of education of and for the present. So let me provide a brief presentation of Badiou's anti-philosophy and the ways in which he portrays a genuine philosopher.

\section{Badiou's anti-philosophy}

The term "anti-philosophy," which Badiou has adopted from Lacan (Clemens \& Bartlett, 2012), has helped him to re-think philosophy, or rather the philosophical practice, through its internal and external relations. Anti-philosophy signifies a conditioned philosophical practice based on the postulate that there are truths-in-worlds, independent of philosophy. However, 
to pursue "anti-philosophy" is also about systematically articulating the means of philosophy. In this way, Badiou turns philosophy against itself. Anti-philosophy has three characteristics (Badiou, 2011b): First, it is a practice disentangled from any pretensions of philosophy to constitute itself as a theory. Second, it recognizes the fact that it is impossible to reduce philosophy to its discursive appearance. Third, anti-philosophy is concurrently destroying the philosophical act, clarifying its noxious character, and affirming the rights of the real.

A genuine philosopher, however, intervenes only when she sees signs in a tangible situation that calls for a new problem. The pamphlet Thinking the Event (Badiou, 2009b) pictures three examples; Plato's dialogue Gorgias, the death of Archimedes, and a scene in Mizoguchi's film The Crucified Lovers. Badiou perceives all three as examples on philosophical situations, which for him are characterized by incommensurable logics.

In Gorgias, there is no relation, no dialogue, between the two types of thought. Badiou holds that Plato has written this dialogue in order to illustrate that there can be two different kinds of thought, two types of thought that remain incommensurable. The discussion between Socrates and Callicles amounts to a relation between two terms devoid of any relation. Callicles argues that the happy man is one who prevails over other's by cunning and violence. Socrates maintains that the happy man is the just man, in the philosophical sense of the term. But the opposition between justice as violence and justice as thought cannot be solved by arguments, since the arguments cannot relate to a shared value. This is not that kind of simple opposition that can be dealt with in terms of arguments covered by a common norm.

Consequently, the discussion is not a real discussion; it is a confrontation. And in such a confrontation, there will be a winner and a defeated. The discussion becomes a matter of winning. The witness to this situation must decide whether to take the side with Socrates or with Callicles. Faced with this situation one must choose between two types of thought. Thus, Gorgias is exemplary because the dialogue illustrates thinking as choice. The task of philosophy is here to throw light on the fundamental choices of thought. In short, Gorgias illustrates how "a philosophical situation consists in the moment when a choice is elucidated; a choice of existence or a choice of thought" (Badiou, 2009b, p. 5).

In the death of Archimedes, there are no common measures, no real discussion, between the right of the state and the creative thoughts embodied in mathematics. Badiou portrays Archimedes as "one of the greatest minds ever known to humanity," an exceptional mathematical genius. Archimedes had the habit of drawing geometrical figures on the sand. One day, as he was contemplating the complicated figures he had drawn on the shore, a Roman soldier, a courier, arrives and tells him that the Roman General Marcellus wishes to see him. It should be said that at that time, the Romans had invaded Sicily, and that Archimedes took part in the resistance by inventing new war machines. Nevertheless, the Roman soldier insists that Marcellus wants to see him. But Archimedes doesn't move. The soldier repeats the message. But Archimedes still doesn't reply. So the soldier, who probably did not have any great interests in mathematics, shouts: "The General wishes to see you". Archimedes barely looks up as he tells the soldier that he wants to finish his mathematical demonstration. Archimedes continues his calculation. But after a while the soldier draws his 
sword and strikes him down. Archimedes falls dead and his body wipes out the geometrical figures in the sand. In this way, the situation illustrates an infinite distance between state power and creative thinking. To Badiou, the death of Archimedes is exemplary as it illustrates that there exists no common measure between the right of the state and the creative thoughts of Archimedes. The task of philosophy is to throw light on this distance.

The scene from Mizuguchi's film The Crucified Lovers illustrates that there are no common measures between love and life. Badiou refers to this film as one of the most beautiful films ever made about love. The film is set in traditional Japan. It is about a young woman married to the owner of a small workshop, an honest man, whom she neither loves nor desires. So she falls in love with a young man, one of her husband's employees. But as adultery was punishable by death in that period of time, the young couple end up fleeing to the provinces. The honest husband tries to protect the runaways by pretending that his wife has left for the countryside. Nevertheless, the couple is captured and sent back to be executed. Here, the film's final images constitute a new instance of the philosophical situation: The two lovers, tied back-to-back on a mule, heading towards their death. Both seem enraptured, devoid of pathos. On their faces there is simply a hint of smile. "Their faces reveal that the man and the woman exist entirely in their love. But the idea of the film, embodied in the infinitely nuanced black and white of their faces, has nothing to do with the romantic idea of the fusion of love and death. These 'crucified lovers' have no desire to die. The shot reveals the very opposite: "love is what resists death" (Badiou 2009b, p. 11). This situation illustrates something extraordinary. It is an exception, an event. Badiou holds that the smile of the lovers is a philosophical situation, since this smile is a sign of something incompatible; a relation that is not a relation. The smile signifies that there is no common measure between the event of love (which turns everything upside down) and the ordinary rules of life (embodied in the city and the laws of marriage). The lovers' smile reveals signs of an exception. The task of philosophy is here to throw light on the value of this exception.

In sum, these three situations illustrate the three vital tasks of philosophy: To clarify the choices of thought; to throw light on the distance between power and creative thinking; and to elucidate the value of the exception, the rupture, the event. To Badiou, a genuine philosopher is someone who

at a deeper level [...] looks for the link between three types of situation - the link between choice, distance and the exception. I argue that a philosophical concept, in the sense that Deleuze ${ }^{1}$ speaks of it - which is to say as a creation - is always what knots together a problem of choice (or decision), a problem

\footnotetext{
${ }^{1}$ Badious anti-philosophy must never be confused with Deleuze's philosophy of difference. Badiou believes philosophy must start in historical situations and events, while Deleuze focuses on the philosophy's use of concepts. Badiou accused Deleuze of being a "hidden trancendentalist". Nevertheless, he expresses deep admiration and respect for Deleuze's philosophical thinking: "Gilles Deleuze: creates, by using concepts, hitherto impossible connections. He weaved thinking like a piece of cloth - with folds and everything "(Badiou 2012b, p. 341).
} 
of distance (or gap), and a problem of the exception (or event) (Badiou, 2009b, p. 13).

The three stories thus illustrate how philosophy is conditioned by incommensurable logics. Badiou here stages the impossible relations between Callicles and Socrates' ways of thinking, between Archimedes and the state, between love and life. Each time there is a paradox, philosophy can take place: "There is philosophy, and there can be philosophy, because there are paradoxical relations, because there are breaks, decisions, distances, events" (Badiou 2009b, p. 16). But what may be the vital mission of a contemporary philosophy of education, and how may this mission be justified? It is exactly these questions Badiou helps to illuminate in his Ethics (Badiou, 2001).

\section{An Ethic of Truth}

Badiou opens his Ethics by offering a critique of "the major 'philosophical' tendency of today", which he sees as a mixture of philosophy and politics. Further, he claims that the current "ethical turn" within philosophy mirrors a Kantian - more than a Hegelian - ethics, since philosophy often comes forward as some indefinite regulations of social life; either in terms of "bio-ethics", "medical ethics", or "professional ethics" implemented by national or transnational ethical committees or councils. Badiou characterizes such regulations as an ethic of nihilism that amounts to "a threatening denial of thought as such" (Badiou, 2001, p. $3)$. On the background of this critique, he outlines a radically different ethic that refers back to particular situations:

Rather than link the word [ethic] to abstract categories (Man or Human, Right or Law, the Other...) it should be referred to particular situations. Rather than reduce it to an aspect of pity for victims, it should become the enduring maxim of singular processes. Rather than make of it merely the province of conservatism with a good conscience, it should concern the destiny of truths, in the plural (Badiou 2001, p. 3).

Badiou names this ethic "an ethic of truth" because, to him, it is the only ethic that enables the continuation of truth-processes. It does so by affirming the three major dimensions of such processes: The event, the fidelity and truth.

An event is to Badiou a conceptualization of the possibility of change. The event is unexpected and unpredictable, something that vanishes and disappears. But it institutes a radical rupture, as it brings to pass instituted outlooks, knowledge and opinions. An event will not in any way appear sensible in the light of everyday rules of life or the rules that usually apply to the situation. The event strikes a radically different logic. As such, it is an ontological "impossibility". In this way, an event is both situated and something that goes beyond the situation: On the one hand, the event is conditioned by a lack - or situated void around which a plenitude of outlooks, knowledge and opinions circulates. On the other hand, 
the event carries a radical novelty, a deep-seated change ${ }^{2}$, a radical different logic that implies that it is impossible to continue to practice - let us say a field of science, politics or arts - in the same way as earlier. Fidelity amounts to the philosophers' persistent exploration of the situation under the imperative of the event itself. Fidelity is thus the name of the processes of immanent and continuing ruptures. Truths (or truth procedures) are internal to the situation and produced by fidelity: "Truth is what the fidelity groups together and constructs, bit by bit" (Badiou, 2001, p. 68).

It should be said the Badiou's concept of truths, in plural, should thus be read in the light of what he considers the mission of philosophy: to identify and highlight new insights or ways of understanding that may occur in and emerge from unforeseen, surprising or disturbing real-worlds events. "Truths" does not belong to philosophy, but rather to the worlds or practices that precedes philosophical analyses. The mission of philosophy is just to identify and reinforce, piece by piece, the truths that may emerge from a tangible event. Again, "truths not only are, they appear" (Badiou 2009a, p. 42).

If we read Badiou's Ethics in light of his two manifestos for philosophy (Badiou, 1992; 2001; 2011a) it becomes evident that the problem for Badiou is that philosophy seems to pretend both to be a science and an ideology. This fluctuation between two types of discourses is due to the fact that philosophy - at least within the French tradition of historical epistemologies has been seen as a discursive construct; or rather a double discursive construct that can never escape the discourse it aims to throw light on. Evil, to Badiou, is the failure of philosophy to break off from or escape these discourses. To him, Evil has three names: (1) To believe that an event convokes not the void of earlier situations, but its plenitude, is Evil in the sense of simulacrum, a "feel-good" image, or terror, (2) to fail to live up to fidelity is Evil in the sense of betrayal, and (3) to identify truth with total power is Evil in the sense of disaster (Badiou, 2001, p. 71). Applied to the many faces of contemporary philosophy of education, Badiou would call for a conditioned philosophy, underlining that

1. it is evil to believe that educational phenomena today assemble not the void, but the plenitude, of earlier situations

2. it is evil, in the sense of betrayal, if philosophy of education fail to live up to fidelity

3. it is evil in the sense of disaster if philosophers of education identify truth-procedures with power

Badiou's philosophy can be read as a continuation of and break from the very tradition he himself critiques: He adopts Canguilhem, Bachelard and Althusser's call for epistemic ruptures. But to him, the solution is not to withdraw philosophy from the field of politics and place it within the field of science, as his predecessors tended to do. Nor is the solution to

\footnotetext{
${ }^{2}$ Badiou states that "an event is a real change in the sense that the existence that is only volatile attributed to the site becomes maximum in such a way that this will be done in the next step independently of the site. We also say that the event makes the non-existent absolute" (Badiou 2009a, p. 585). It should be noted, however, that his term "site" has a double meaning: On the one hand it denotes "tópos", a term used within rhetoric to indicate general ways of thinking. On the other hand, it denotes "space", a term used in mathematical set theory to indicate relationships between collections of objects or amounts (Strand, 2017).
} 
place philosophy within the field of politics, in the way some of his contemporaries seem to do. Badiou rather turns to philosophy itself as he clearly distinguishes the rules of philosophy from the discourses that are its conditions, be it science, politics, love or art. So, let us again take a closer look at what contemporary philosophers of education may learn from Badiou.

\section{Conditioned philosophy}

Badiou holds that political, scientific, artistic and amorous discourses, or praxes, precedes and orient philosophy. But philosophy should never be fused with these conditions (Badiou, 1992; 2008). However, Badiou uses the term "condition" in two ways: On the one hand, it is the name for that which marks truth-procedures in their compositional singularities. On the other hand, "condition" is the name for the form or shape that creates the situation (or condition) for these autonomously operating truth-procedures. Thus, a "condition" is or will necessarily include philosophy. There is never an independent philosophy. Philosophy cannot think for itself. But philosophy - and philosophy only - contains the resources to reveal and preserve the being and appearance of truths in worlds. "In this sense the conditions prescribe, and absolutely so, the possibilities of a philosophy's form” (Bartlett, 2006, p. 43).

Consequently, Badiou calls for a return to philosophy. His mission is to strengthen and renew the task of philosophy: "... at least if philosophy is to count for something in life, to be something other than an academic discipline" (Badiou 2009b, p. 12). Some may even claim that Badiou aims at moving back into Plato's cave in order to "return to philosophy itself" (Bartlett, 2006; Pluth, 2010): A philosophy of the cave may witness an event and, if truthful to that glimpse and living up to fidelity, introduce the truth by naming it in worldly situations.

Arguing against those who tend to conflate politics with philosophy and also truth with knowledge, Badiou (2006; 2011a) contends that there is no such thing as a philosophical truth. The purpose of philosophy is not to develop a credo. Philosophy cannot and will not tell what particular position to take in politics or science. Because truths are produced and continue to emerge in other, non-philosophical spheres of life: In love, art, politics and science. However, philosophy contains the resources to reveal and preserve the appearance of truths. In this way, philosophy deals with logical transformations; truths as creation. But philosophy is neither the interpreter nor mediator of truths. The task of philosophy is rather to "examine the constitution, in singular worlds, of the appearing of truths, and therefore on what grounds (sic) the evidence of their existence" (Badiou 2009a, p. 9). This distinction between philosophy and real life, in addition to Badiou's idea of the mission of philosophy, help to understand Badiou's discussion on education.

\section{Education by truths}

In a short essay - Art and Philosophy - Badiou formulates his axiom that "the only education is an education by truths" (Badiou, 2005a, p. 14). An education by truths, according to Badiou, operates through a subtraction from the state of the situation and proposes a different direction as regards to the true life. The pedagogical effect of truths-in-worlds or truthprocedures, however, is conditioned. First, by finite conditions, which are the truthprocedures emerging within the field of science, art, politics or love. Second, by an infinite 
condition, which is Truth, or the way in which philosophy identifies, articulates and affirms truths-in-worlds by thinking them together. Education is thus part of a triadic knot: condition - philosophy - education. Badiou's notion of education has therefore a distinct form, very different from the forms inscribed in and represented by the current state.

In Art and Philosophy Badiou explores this concept of education in relation to one of its finite conditions, namely art. This is actually the only text in which Badiou addresses education as education. He here claims that artistic apprenticeship is a key to education. To him, art "is pedagogical for the simple reason that it produces truth and because 'education' has never meant anything but ... to arrange the forms of knowledge in such a way that some truths may come to pierce a hole in them," (Badiou, 2005a, p. 9). The fact that Badiou considers art as a truth procedure sui generis, both immanent and singular, makes it impossible to think the triadic knot of art, philosophy and education through a didactic, romantic or classical schema.

A didactic schema is problematic because it reflects an idea that art is incapable of truth: Here, truth is conceived external to art. This schema reduces art to a means of achieving an external goal. The didactic schema turns art into an instrument, a device to "shape" the students within an already given template, or an apparatus for "educating" the public. Consequently, within this perspective, the control of art seems vital. Because "... if the truth of which art is capable comes to it from outside - if art is a didactics of the senses - it follows, and this point is crucial, that the "good" essence of art is conveyed in its public effect and not in the artwork itself," (Badiou, 2005a, p. 3). Therefore, within a didactic schema, the norm of art turns out to be education, and the norm of education philosophy. In other words, art and philosophy are here both considered instrumental to education.

A romantic schema opposes this idea. However, Badiou questions how this romantic schema glorifies art: The romantic schema makes art absolute, as art alone is capable of truth. Thus, art itself educates. Art completes what philosophy can only point at. Consequently, the romantic scheme is dealing with the truth of an artwork, never truths-in-worlds - which may be quite different from what the artwork itself exposes. Truth is immanent, but never singular. In other words, the romantic schema relates to art as if art represents the truth itself without regard to the situation.

The classical schema mirrors an idea that art has a therapeutic function. To Badiou, this schema is problematic since "art must be liked because "liking" signals the effectiveness of catharsis, the real grip exerted by the artistic therapy of the passions," (Badiou, 2005a, p. 4). A classical schema delegates to art a public service to capture, mirror, and shape communal desires and ambitions. Consequently, the relation between art and education can be described in terms of 'Bildung', or cultivation. A classical schema thus limits art to those aspects recognized as meaningful. Moreover, it reduces philosophy to aesthetics.

In short,

Didacticism, romanticism, and classicism are the possible schemata of the link between art and philosophy - the third term of this link being the education of subjects, the youth in particular. In didacticism, philosophy is tied to art in the 
modality of an educational surveillance of art's purpose, which views it as extrinsic to truth. In romanticism, art realizes within finitude all the subjective education of which the philosophical infinity of the idea is capable. In classicism, art captures desire and shapes [éduque] its transference by proposing a semblance of its object. Philosophy is summoned here only qua aesthetics: It has its say about the rules of "liking" (Badiou, 2005a, p. 5).

Didacticism permeates the public use of art; romanticism reveals itself as pure promise, while classicism reduces art to a service to psychoanalysis. To Badiou, these three schemas distort the relation - or rather "non-relation" - between art and philosophy, with the ugly consequence that the pedagogical theme collapses: "None of these schemas operates a pedagogical form that is both singular and immanent" (Bartlett, 2006, p. 53). Badiou's ambition, however, is to rescue the pedagogical function of art. He thus proposes a fourth schema based on the consideration of art as a truth-procedure sui generis:

Art itself is a truth procedure. Again; the philosophical identification of art falls under the category of truth. Art is a thought, or rather, the truths that it activates are irreducible to other truths - be they scientific, political, or amorous. This also means that art, as a singular regime of thought, is irreducible to philosophy (Badiou, 2005a, p. 9).

What art educates for is nothing but its own existence. The pedagogical theme is simply a question of encountering that existence. Philosophy's task is to unveil artistic truthprocedures in their very being. In this way, philosophy becomes the go-between in the encounters with artistic truths, because philosophy has the power to point to the configurations of these truths, reveal their thinking subjects, and help to distinguish truth from opinion.

Badiou's undeniably novel position on the triadic knot of art, philosophy and education firstly recognizes art as a genuine truth-procedure; secondly refuses to mix philosophy up with these truths while similarly pointing out that philosophy is duty-bound to make truths-in-worlds manifest; and thirdly claims that the only education is an education by truths. In short "education amounts to nothing more and nothing less than establishing the effect of an encounter as a transformation," (Bartlett, 2006, p. 55). However, what is it that is being transformed?

The question is pertinent, since Badiou certainly does not speak about an education by the state. An education by the state would simply just perpetuate, replicate or reproduce the norms, laws, procedures and worldviews already contained by the situation. An education by truths, by contrast, is a transformative, open-ended and ongoing procedure instituted by an exception, a rupture, or event. The ambition is to nurture a subject of and to truth. Such an education does not follow any curriculum or pre-established methods in its promotion of ontological awareness, curiosity and search for non-knowledge.

What one must be able to require of oneself, at the right time, is rather the capacity for adventure to which ontology testifies, in the heart of transparent rationality, by its 
recourse to the production of the absurd; a detour in which the extension of their solidity may be restituted to the equivalence: 'He shatters his own happiness, his excess of happiness, and to the Element which magnifies it, he rends, but purer, what he possessed' (Badiou, 2005b, p. 254).

In sum, an education by truths transforms the thinking subject. Such an education operates through a subtraction from the situation and proposes a different direction in regards to the true life. In other words, an educated subject is subtracted from any concept of the situation, and may next contribute to a radical transformation of the world. Badiou's hyper-translation of Plato's allegory of the cave is an illustrative example (Badiou, 2012a).

\section{An illustrative example}

When Badiou states that "the only education is an education by truths," it is exactly this notion of education he illustrates by his hyper-translation of Plato's Republic (Strand, 2016). Plato's Republic treats the topics of morality and justice, but also other issues, such as education, politics and images of the good. In chapter nine, Socrates portrays "a situation which you can use as an analogy for the human condition - for our education or lack of it," (514a). The allegory tells a story of prisoners chained to the wall of a cave since early childhood. Their legs and necks are fixed, so they are forced to look in one direction only. However, a fire behind their backs throws shadows on the wall in front from the people, puppets, objects or animals passing by. The prisoners have never experienced life outside the cave, not even realized that they are inside a cave, so to them these shadows constitute reality.

Badiou transforms this allegory to a fable of a movie theater: "I'll try to paint you a picture, with shadow and light intermingled," Socrates says (Badiou, 2012a, p. 212). The fable tells a story of a gigantic movie theater, a full house of "tens of thousands of spectators" chained to their seats and with rigid headphones covering their ears, holding their heads in place. The audience gazes at an enormous screen in front, which goes all the way up to the ceiling. Behind them there are huge projectors throwing a white light and shadows of "a chaotic parade" on the screen. The colorful parade consists of a myriad of characters, such as puppets, robots, animals, soldiers, gangs of youths, cultural consultants, turtledoves and scythe-bearers that shout, sing, dance, play or just move silently along a wooden walkway in front of the projectors.

Next, we are asked to imagine that a member of the audience is forced to stand up, turn his head and look at the light. The sight hurts his eyes, so his impulse is to turn back to his seat. However, "a bunch of tough guys" violently forces him to leave the movie theater through a small side door, enter a muddy tunnel, and climb up into the open air. "At first he is blinded by the glare of everything and can see nothing of all the things about which we routinely say: "This exists, this is really here," Badiou 2012a, p. 214).

After being used to the light, he enjoys the reflection of flowers and trees in the water, before he eventually finds pleasure in the flowers themselves. As the night falls, he lifts his head to the sky and sees the moon and the stars. "Finally, one morning, he sees the sun, not in the 
ever-changing waters, or in its purely external reflection, but the sun itself, in and for itself, in its own place," (Badiou, 2012a, p. 214). Plato suggests that the freed prisoner "feel happy about his own altered circumstances," (516c) and Badiou that "he is glad to have been forced to leave," (Badiou, 2012a, p. 215).

The allegory pictures a move away from illusio (illusion), beyond doxa (common beliefs) and towards noësis (insight, wisdom or knowledge of the good). We may label this process paideia (Jaeger, 1973), Bildung (Humboldt, 1993) or simply education. The allegory carries three dimensions that together portray this educational process: The situation, the event and the subject. The situation is the movie theater or "the cave of illusion," in which the artificial images and the shadows of the simulacra are taken to signify the world. The event is the unexpected turning of the head; the unpredictable and violent enforced escape; the surprising ascension into the open air; and the experience of the sun and the beauty of the objects of the world outside. The subject is a thought-process that gradually unfolds the imports of the event by addressing the whole situation and unfolding the infinity of the truth exposed by the event.

Badiou's fable shows that education is simply about directing, or re-directing, thinking towards truths. Socrates sums up: "education isn't what some people claim it is" (Badiou, 2012a, p. 218). Education is not a question of a lack of the capacity of sight. It is neither about a lack of the capacity of knowledge. Every subject has such capacities. Education is rather about turning the subject into the right direction. "So education isn't a matter of imposing, but rather of orienting: It is a technique of conversion..." (Badiou, 2012a, p. 218).

In sum, Badiou portrays education as a "reorientation" and "incorporation into a truth". Thought has its own power, which it can never lose. However, whether thought is useful or useless, constructive or destructive, valuable or damaging depends on the direction in which that power is turned.

\section{Badiou's call}

To sum up, I have here pointed to Badiou's overall ambition of rethinking, renewing and thereby strengthening philosophy as an academic discipline. His rethinking of the status of the immanent real goes well with his ambition to make sense of the potential of radical innovations in, or transformations of, any given situation. "Understood in this way, and only in this way, philosophy really is that which helps existence to be changed" (Badiou, 2009b, p. 13). Moreover, I have pointed to the way in which Badiou sharply rejects the current tendency to create philosophical credos: Philosophy is different from real life. And real life can never be turned into philosophy, because to him, real life always precedes philosophy. So, Badiou's call is for philosophy to respond to real life situations through a diligent, meticulous and non-dogmatic engagement with incommensurable aspects of the material world.

But then again, to what degree do current philosophy respond to what is going on? The reality of today is that young Europeans, including Nordic youths, grow up in a globalized world marked by economic inequalities, epidemic threats, climate change and an uncertain 
future. Youth revolts, emerging fascism and a democratic recession may indicate that the societies' social contract is put to test. But what kind of philosophy carry a potential to respond well to this situation? To what degree may Badiou in fact offer a philosophy for the present? In addition, does his philosophical system carry a potential to strengthen the topicality and relevance of a philosophy of education of and for the present? It seems like an impossible dilemma, on the one hand, to claim that philosophy carry the potential to help existence to be changed and, on the other hand, to claim a sharp distinction between philosophy and real life.

\section{The timeliness and relevance of philosophy of education}

It may seem contradictory that Badiou sharply rejects the tendency to create philosophical credos, as he himself has published no less than two philosophical manifests and several polemical writings on the (missing) timeliness and relevance of philosophy. In all, it appears that Badiou - and even philosophy itself - is surrounded by a number of contradictions and dilemmas: Badiou's ambition is to return to, restore and enhance traditional philosophy while also strengthening its timeliness and relevance. He clearly takes a stance against the current tendency to engage in polemic philosophy, while he at the same time publishes polemical texts; He portrays a genuine philosopher as one who constructs her own problems, while he at the same time advocates a first and conditioned philosophy. An obvious dilemma is how it is possible to be rooted in tradition while simultaneously wanting to radically renew it. It is exactly this dilemma Badiou discusses in his somewhat overlooked essay "What Is a Philosophical Institution?" (Badiou, 2006).

In this essay, Badiou addresses the dilemma by introducing the metaphor of a theatre. Philosophy is a theatre containing a myriad of voices, discourses and truth procedures. It is a tragic theatre, because conflicting events, polemical scenes, and separate subjects are taking place. It is also a comic theatre, as grotesque figures like the sophist, the anti-philosopher, the reactionary, the obscure or the ideologue are here being divulged. The theatre is huge, with numerous scenes, multiple actor groups and myriads of spectators, as Badiou's doctrine of a conditional philosophy allows for several stages and multiple groups of actors. Armed with this doctrine and Badiou's concepts of event, fidelity and truth, it is possible to re-read the history of philosophy, reorganize it on the basis of various configurations of truth procedures, and point out how these truths are more or less recognized by earlier philosophers. This "history of truth procedures" (which should not be confused with a person's history) is to Badiou a history of ideas that next generates more scenes, involving several groups of actors and affects more spectators. Consequently, it becomes clear that to Badiou, the genuine philosopher is not a lone actor in the desert of theories. On the contrary, the genuine philosopher is a sophisticated artist, a scientist at the edge of madness, an amorous lover, and a socially engaged human being surrounded by - and interacting with - diverse actors and deeply committed and involved individuals. Philosophy is a diverse, varied and rich engagement, in which the mission is to see the situation (the world), appreciating the unusual, and asking new questions. 
Philosophers of education are invited to participate in this theatre. The commitment concerns the incommensurable relationship between philosophy and education, in which a productive thinking emerge in the distinction between the rules of philosophy and the (educational) discourses that condition philosophy, whether it is about art, science, love and politics. The task of philosophy of education is to read the truth procedures emerging from these four discourses, and point to their educational potentials. Philosophy of education must think that which is impossible to think within the given categories of the discourses. This can happen through a thorough reading of the situation (the world), by appreciating the unusual, and by asking new questions.

\section{References}

Badiou, A. (1992). Manifesto for Philosophy. New York: State University of New York Press Badiou, A. (2001). Ethics. An Essay on the Understanding of Evil. London: Verso Badiou, A. (2005a). Handbook of Inaesthetics. Stanford, CA.: Stanford University Press Badiou, A. (2005b). Being and Event. London: Continuum

Badiou, A. (2006). What is a Philosophical Institution? Or: Address, Transmission, Inscription. Cosmos and History: The Journal of Natural and Social Philosophy, 2 (12), $9-14$

Badiou, A. (2008). Conditions. London: Continuum

Badiou, A. (2009a). Logics of Worlds. Being and Event II. London: Continuum

Badiou, A. (2009b). Thinking the Event. In: Badiou, A. \& Zizek, S.: Philosophy in the Present (pp. 1 - 48). Cambridge: Polity Press

Badiou, A. (2011a). Second Manifesto for Philosophy. Cambridge: Polity press

Badiou, A. (2011b). Wittgenstein's anti-philosophy. London: Verso

Badiou, A. (2012a). Plato's Republic. Cambridge: Polity Press

Badiou, A. (2012b). For a Tomb of Gilles Deleuze. In: The Adventure of French Philosophy (s. 339 - 341). London: Verso

Badiou, A. (2017). The true life. Cambridge: Polity press

Bartlett, A. J. (2006). Conditional notes on a New Republic. Cosmos and History. The Journal of Natural and Social Philosophy, 2 (1-2), 39 - 67

Bartlett, A. J. (2011). Badiou and Plato. An education by truths. Edinburg: Edinburg University Press

Clark, J, (2006). Philosophy of Education in Today's World and Tomorrow's: A View from 'Down Under'. Paideusis, 15 (1), 21 - 30

Clemens, J. \& Bartlett, A. J. (2012). 'The Greatest of Our Dead': Badiou and Lacan. In: Bowden, S. \& Duffy, S. (eds.). Badiou and Philosophy (s. 177 - 202). Edinburgh: Edinburgh University Press

Curren, R. (ed.) (2007). Philosophy of Education. An Anthology. Oxford: Blackwell Hallward, P. (2003). The One or the Other. French Philosophy Today. Angelaki. Journal of the Theoretical Humanities, 8 (2), 1 - 32.

Hayden, M. J. (2012). What Do Philosophers of Education Do? An Empirical Study of Philosophy of Education Journals. Studies in Philosophy and Education, 2012 (31), 127 
Heyer, K. (2010). Introduction: Alain Badiou: 'Becoming subject' to education. In: Heyer (ed.). Thinking Education through Alain Badiou (pp. 1-7). Oxford: Wiley-Blackwell James, I. (2012). The New French Philosophy. Cambridge: Polity press.

Phillips, D. C. (2010). What is Philosophy of Education? In: Bailey, R., Barrow, R., Carr, D., \& McCarthy, C. (eds.). The Sage Handbook of Philosophy of Education (pp. 3 - 19). Los Angeles: Sage

Pluth, E. (2010). Badiou. A Philosophy of the New. Cambridge: Polity Press

Ruitenberg, C. (ed.) (2010). What do philosophers of education do? And how do they do it? Oxford: Wiley-Blackwell

Siegel, H. (2009). Introduction: Philosophy of Education and Philosophy. In: Siegel (ed.). The Oxford Handbook of Philosophy of Education (pp. 3 - 8). Oxford: Oxford University Press

Smeyers, P. (2006). What Philosophy Can and Cannot Do for Education. Studies in Philosophy and Education, 2006 (25), $1-8$

Smeyers, P., Ruitenberg, C., Waghid, J. \& Strand, T. (2013). Publish Yet Perish. On the Pitfalls of Philosophy of Education in an Age of Impact Factors. Studies in Philosophy and Education

Strand, T. (2012). Den pedagogiske filosofiens oppdrag [The Mission of Philosophy of Education]. Studier i Padagogisk Filosofi, 1 (1), 4 - 16

Strand, T. (2016). Alain Badiou on political education. In: Marianna Papastephanou (ed.), Cosmopolitanism: Educational, Philosophical and Historical Perspectives. Dordrecht: Springer

Strand, T. (2017). "I Create Silence". Revisiting the Ancient Dispute between Poetry and Philosophy. In: Strand, T. et. al. (eds.). Philosophy as Interplay and Dialogue. Viewing landscapes within philosophy of education (s. 53 - 75). Münster: LIT Verlag

Strand, T. (2020). Alain Badiou and Education. G. W. Noblit (ed.). Oxford Research Encyclopedia on Education. Oxford: Oxford University Press 